\title{
Issues of Maternal and Child Health Care Services among Rural and Urban Population in Selected Districts of Assam
}

\author{
Smrita Barua \\ MPS, IIPS, Mumbai, India
}

\begin{abstract}
In this paper we study the variation in the issues regarding maternal and child health care services among rural and urban population in some selected districts of Assam. Five districts are selected to study the issues of maternal and child health care. These districts are selected on the basis of region i.e. upper lower, middle and hills regions of Assam. Secondary data are collected for these five districts from various sources of government publication. The data has been analyzed with the help of frequencies, percentages, rates and ratios and are presented in different tables and graphs. Results of the analysis shows that regional difference along with education has impact on utilization of maternal and child health care services.
\end{abstract}

Keywords: child and women health, rural, urban, population, districts, Assam

\section{Introduction}

Assam is the land of hills and valleys and mighty river Brahmaputra flows from east to west dividing the Assam into two parts. The name "Assam" is derived from" Asom" which, in Sanskrit means unequalled or unrivalled. Assam is one of the more prominent states in India and has been involved in the political and social issues of the nation for long time.

The population of Assam according to 2011 census stands at about 31 million making the $14^{\text {th }}$ most populated state in India with a growth rate of about $17 \%$ which is very close to the national growth rate of $17 \%$. The literacy rate in the state is improved tremendously to $73 \%$ from the last decade which was $63.25 \%$. The sex ratio in the state is 954 females to 1000 males and the child sex ratio is 962 . These indicators show that Assam is developing itself to match up with the Nation's development and progress.

Health is an essential component for a region for its development and internal stability. Assuring a minimum level of health care is vital for a region for its development. Safe motherhood practices and child survival programs are important in a region having high infant and child mortality. Assam is one of the states having high infant and child mortality, maternal mortality and has regional disparities of maternal and child health care.

\section{Objective of the Study}

Our objective of this paper to study the variation in the issues regarding maternal and child health care services among rural and urban population in some selected districts of Assam.

\section{Methodology and Data Base}

The study is based on purely secondary data. Districts are chosen such that it represent upper and lower and hills area of Assam. The selected districts are Dhubri, Kamrup, Karbi
Anglong Jorhat and Tinsukia. Secondary data for these districts are collected from the source of Annual health survey 2011-2012, Fact sheet Assam and census of India, 2011. The available literatures on the studies conducted on maternal and child health care and utilization pattern has also used. The data has been analyzed with the help of frequencies, percentages, rates and ratios and are presented in table, graphs.

\section{Brief Description of Selected Districts}

Dhubri: Dhubri district is an administrative district in the state of Assam. It situated in the extreme west corner of Assam. The district head quarters are located in Dhubri town which is situated at $290 \mathrm{Km}$ from Guwahati, the state capital. The river Brahmaputra flows through the district. The district is bounded both by inter-state and international border i.e. West Bengal and Bangladesh in the west, Goalpara and Bongaigaon district of Assam and Garo hills of Meghalaya in the east, Kokrajhar district in the north, Bangladesh and state Meghalaya in the south. Covering an area of 2838 sq. Kms. including forests, rivers, hills etc; the district has become the most densely populated district in India with a density of 1171 persons per sq. Kms.(as per 2011 Census). The district has four urban areas. As per the census 2011 the total population of Dhubri is 1,949,258. Literacy rate is 58.34 which is much below the state average level. Sex ratio Dhubri district is 953 per 1000 male according to 2011 census. But the child sex ratio is 968 which higher than state ratio.

Kamrup : Historically present Assam was referred to as Kamrupa in many of the ancient Indian literature. Till the Ahom conquest, Kamrup district was known as Pragjyotishpur. It is now(after 1980) an administrative district of Assam state. This district is located in the western part of Assam and embodies the Kamrupi dialect and culture. Kamrup district occupies an area of 4345 square kilometers. According to the 2011 census Kamrup district has a population of $1,517,202$. The district has a population density of 436 persons per square kilometers. It population 


\section{International Journal of Science and Research (IJSR) \\ ISSN (Online): 2319-7064 \\ Index Copernicus Value (2013): 6.14 | Impact Factor (2014): 5.611}

growth rate over the decade 2001-2001 was $15.67 \%$. Kamrup has a sex ratio of 946 females for every 1000 males and a literacy rate of $72.81 \%$.

As per the 2011 census demographic profile of the district shows that $90.62 \%$ people live in rural areas. The sex ratio as per 2011 census is 949 and the sex ratio for children (0-4 years) is 970 . But the overall sex ratios along rural and urban region are below than the state average sex ratio. It is the third highest district in the state in terms of literacy rate. The work participation rate shows that work participation rate is higher for the urban people but the people living in rural areas their work participation rate is lower than the state $s$ average.

Karbi Anglong: Karbi Anglong is the largest amongst the 27 administrative districts of Assam in terms of area. It occupies an area of 10434 square kilometers. According to 2011 census total population of this district is 956,313. It is comparatively equivalent to the Island of' Hawaii". The sex ratio of the district is almost equal to the state average level. But the rural sex ratio is far below than the average sex ratio of the state. Except the sex ratio among the children (0-4 years) in the urban region, child sex ratio is lower than the state average level. Work participation rate over all and both for rural and urban region are below the state average. Literacy rate of the district is $73.52 \%$. Most of the people in the district are vulnerable. Government should take progressive strategy for over all development of the district.

Jorhat : Jorhat is an administrative district of Assam, located in the central part of Brahmaputra. Earlier Jorhat was a sub division of Sibsagar district. Total population of Jorhat district is 1092256 according to 2011 census. Males are 556805 and females are 535451 . Its total area is 2851 square
$\mathrm{Km}$. It is $12^{\text {th }}$ largest district in the state by population and area. Sex ratio of the district is 962 which is above than state average of 954 . Literacy rate of the district is $82.15 \%$ which is better than the state average. Male literacy rate is 87.63 and Female literacy rate is 76.45 . Apart from sex ratio at birth and sex ratio for (0-6) years is 964 .Population growth rate of Jorhat district is 9.31 according to 2011 census.

Tinsukia: Tinsukia is located in the upper part of Assam and is surrounded by Arunachal Pradesh in the south-east, Dibrugarh district in the south -west and Dhemaji district in the north. Tinsukia has a geographical area of 3790 square kilometer. It was declared as the $23^{\text {rd }}$ district of Assam on ist October 1989 with three subdivisions Tinsukia, Margherita and Sadiya. Tinsukia district is situated 480kilometers north east of Guwahati and 84 kilometers away from the border with Arunachal Pradesh. The sex ratio of the district for children and over all in urban region are below the state average level. The work participation rate is higher than the state average level which indicates that people are more active and eventually pulls up the state average

Table 1: Percentage of rural \& urban population in the selected districts of Assam

\begin{tabular}{|c|c|c|c|c|c|}
\hline \multicolumn{6}{|c|}{ Rural \& Urban Population Distribution } \\
\hline \multirow{3}{*}{ State/ District } & \multirow{2}{*}{ Total } & \multicolumn{2}{|c|}{ Rural } & \multicolumn{2}{c|}{ Urban } \\
\cline { 3 - 6 } Assam & $\mathbf{1 7 8 1 8 3 3}$ & $\mathbf{1 4 9 5 4 7 7}$ & $\mathbf{8 3 . 9 3}$ & $\mathbf{2 8 6 3 5 6}$ & 16.07 \\
\hline Dhubri & 49763 & 45208 & $\mathbf{9 0 . 8 5}$ & 4555 & 9.15 \\
\hline Jorhat & 170181 & 133876 & $\mathbf{7 8 . 6 7}$ & 36305 & 21.33 \\
\hline Kamrup & 161026 & 95306 & $\mathbf{5 9 . 1 9}$ & 65720 & 40.81 \\
\hline Karbi Anglong & 65660 & 51417 & $\mathbf{7 8 . 3 1}$ & 14243 & 21.69 \\
\hline Tinsukia & 137539 & 113745 & $\mathbf{8 2 . 7 0}$ & 23794 & 17.30 \\
\hline
\end{tabular}

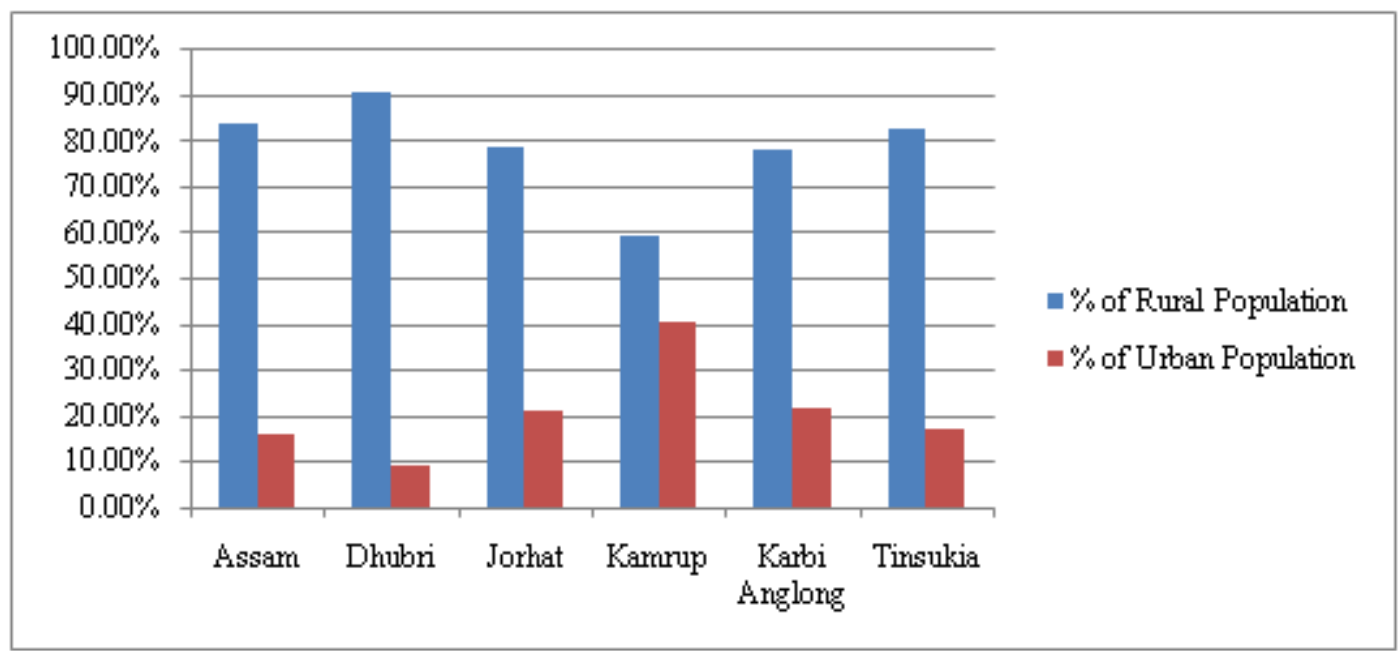

Figure 1: Percentage of rural \& and urban population in the selected districts of Assam

Table 2: Socio economic and demographic situation in the selected districts of Assam:

\begin{tabular}{|c|c|c|c|c|c|}
\hline Socio economic demographic indicators & Dhubri & Kamrup & Karbi Anglong & Jorhat & Tinsukia \\
\hline Total population & $1,949,258$ & $1,517,542$ & 956,313 & $1,092,256$ & $1,327,929$ \\
\hline Sex ratio total & 953 & 949 & 951 & 962 & 952 \\
\hline \%Urban population & 10.45 & 9.38 & 11.81 & 20.19 & 19.94 \\
\hline \%Rural population & 89.55 & 90.62 & 88.19 & 79.81 & 70.06 \\
\hline Sex ratio (0-4) & 969 & 970 & 959 & 964 & 962 \\
\hline Literacy rate & 58.34 & 75.55 & 69.25 & 82.15 & 69.66 \\
\hline Work participation rate & 52.1 & 47.5 & 44.7 & 56.6 & 60.3 \\
\hline
\end{tabular}

Volume 4 Issue 11, November 2015 
International Journal of Science and Research (IJSR)

ISSN (Online): 2319-7064

Index Copernicus Value (2013): 6.14 | Impact Factor (2014): 5.611
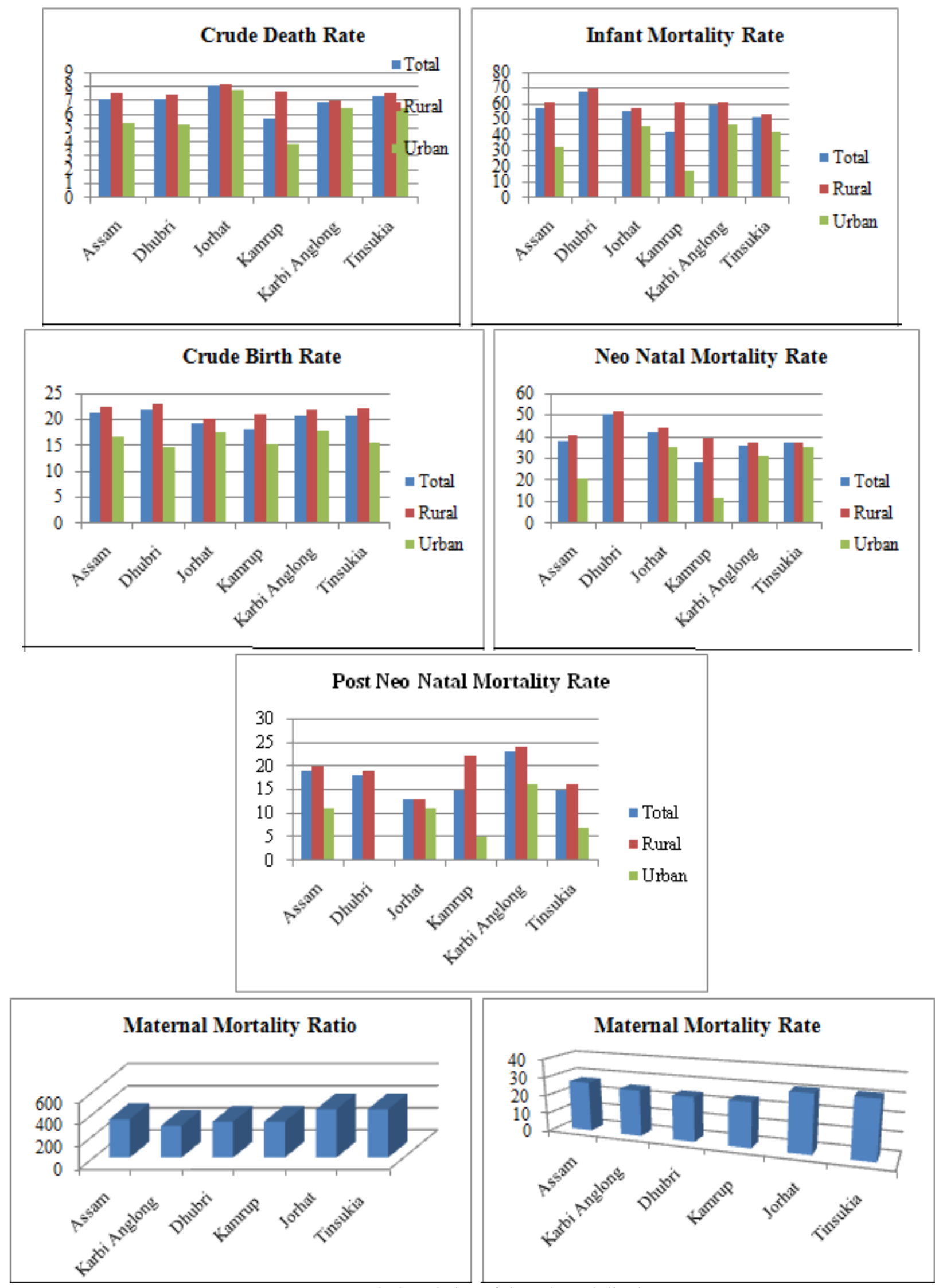

Figure 2: Vital statistics of the selected districts

\section{Issues of Maternal and Child Health Care} Services

Antenatal care: Antenatal care (ANC) refers to pregnancyrelated health care by a doctor or health worker in a medical facility or at home. Antenatal care includes early registration of all pregnancies, ideally within first trimester (before 12 week of Pregnancy). However even if a woman comes late in her pregnancy for registration, she should be registered and care given to her according to gestational age. Minimum 


\section{International Journal of Science and Research (IJSR) \\ ISSN (Online): 2319-7064 \\ Index Copernicus Value (2013): 6.14 | Impact Factor (2014): 5.611}

four antenatal check-ups is needed for pregnant woman . First visit to the antenatal clinic as soon as pregnancy is suspected, $2^{\text {nd }}$ between $4^{\text {th }}$ and $6^{\text {th }}$ month(around 26 weeks), $3^{\text {rd }}$ at $8^{\text {th }}$ month (around 32 weeks) and $4^{\text {th }}$ at $9^{\text {th }}$ month(around 36 weeks) . The Safe Motherhood initiative proclaims that all pregnant women must receive basic but professional antenatal care. Antenatal care can contribute significantly to the reduction of maternal morbidity and mortality because it also includes advice on the correct diet and the provision of iron and folic acid tablets to pregnant women, besides medical care. Antenatal care constitutes one of the key elements to promote safe motherhood. Improved nutritional status, coupled with improved antenatal care, can help to reduce the incidence of low birth weight babies and thus reduce perinatal, neonatal and infant mortality. The Antenatal care can be studied through indicators like percentage of mothers who received any ANC, number of Antenatal checkup, percentage of mothers who received at least 3 or more ANC and so on. The number of ANC visits by currently married pregnant women indicates the intensity of utilization of maternal health care services by the pregnant women.

The graphs below indicate the intensity of utilization of maternal health services by pregnant women. From the graph it can be seen that amongst currently married pregnant women in rural \& urban region in all the selected districts, who receives any antenatal checkup, visits antenatal checkup in the first trimester and taking tetanus toxoid vaccines Jorhat, Tinsukia and Kamrup are ahead than other two region. Similarly for pregnant women taking IFA tablets performance of Jorhat and Kamrup are better than the remaining districts. In rural and urban Assam performance of Jorhat is better than other districts regarding mother health care services.
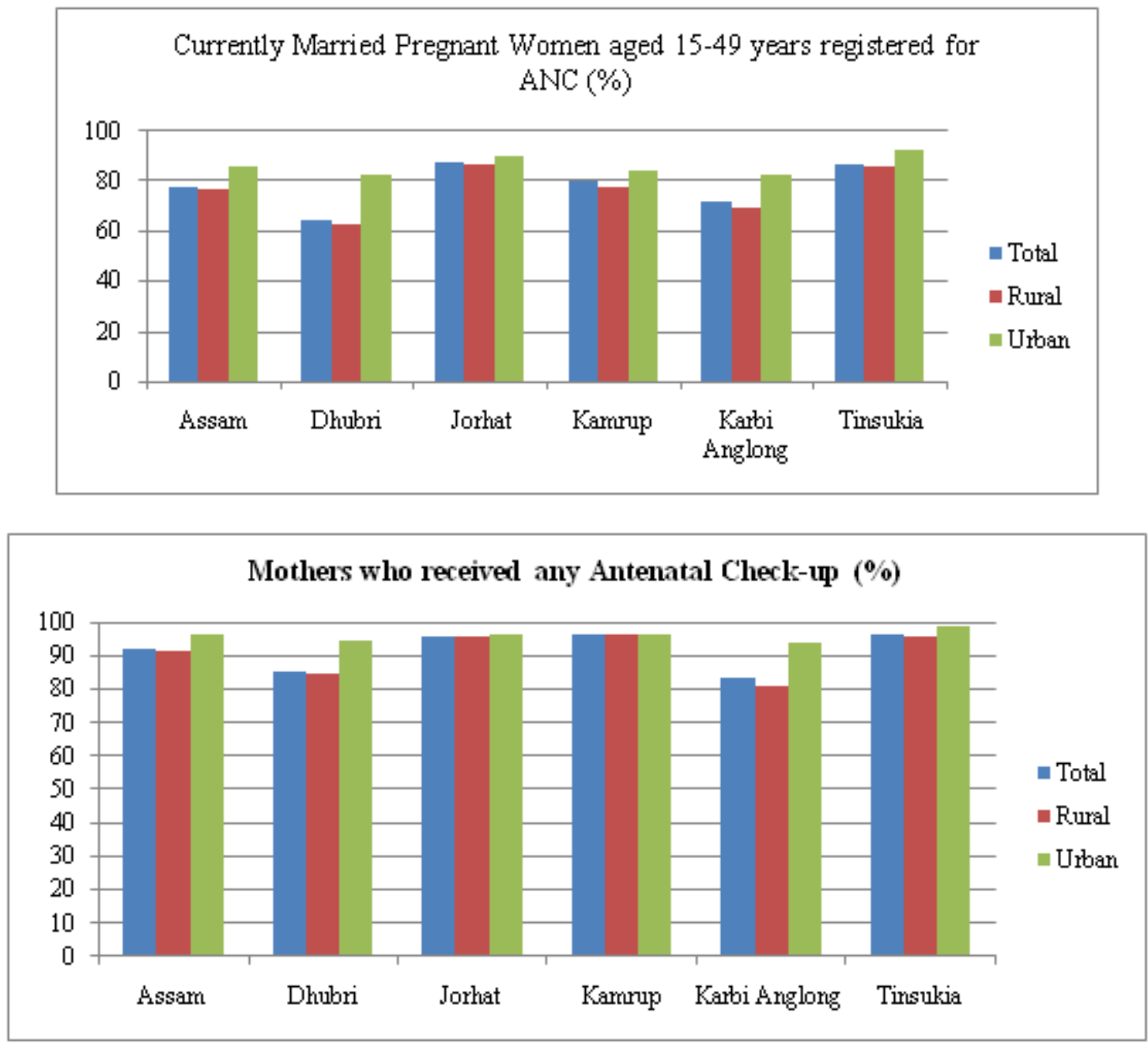
International Journal of Science and Research (IJSR)

ISSN (Online): 2319-7064

Index Copernicus Value (2013): 6.14 | Impact Factor (2014): 5.611
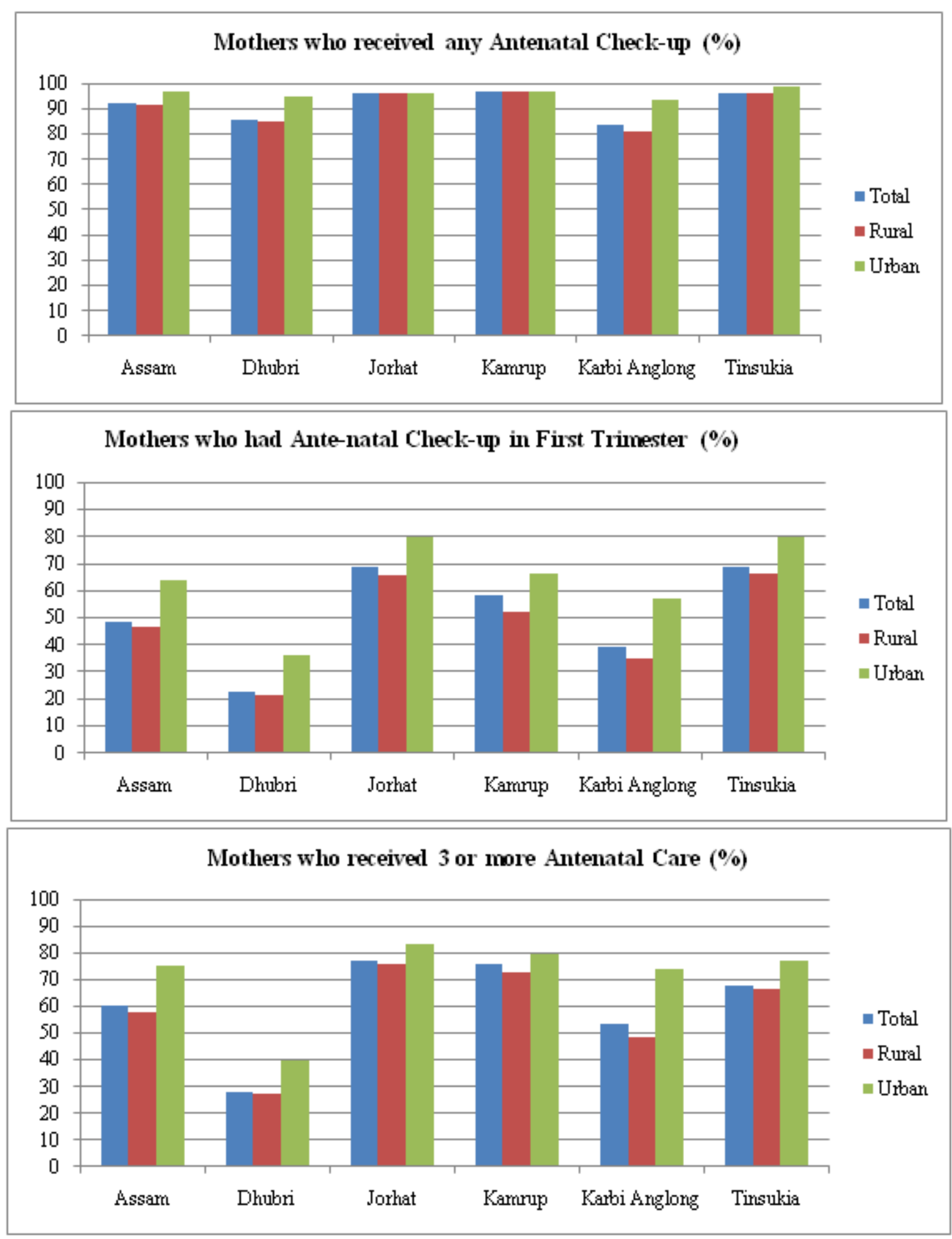

Volume 4 Issue 11, November 2015 


\section{International Journal of Science and Research (IJSR) \\ ISSN (Online): 2319-7064}

Index Copernicus Value (2013): 6.14 | Impact Factor (2014): 5.611

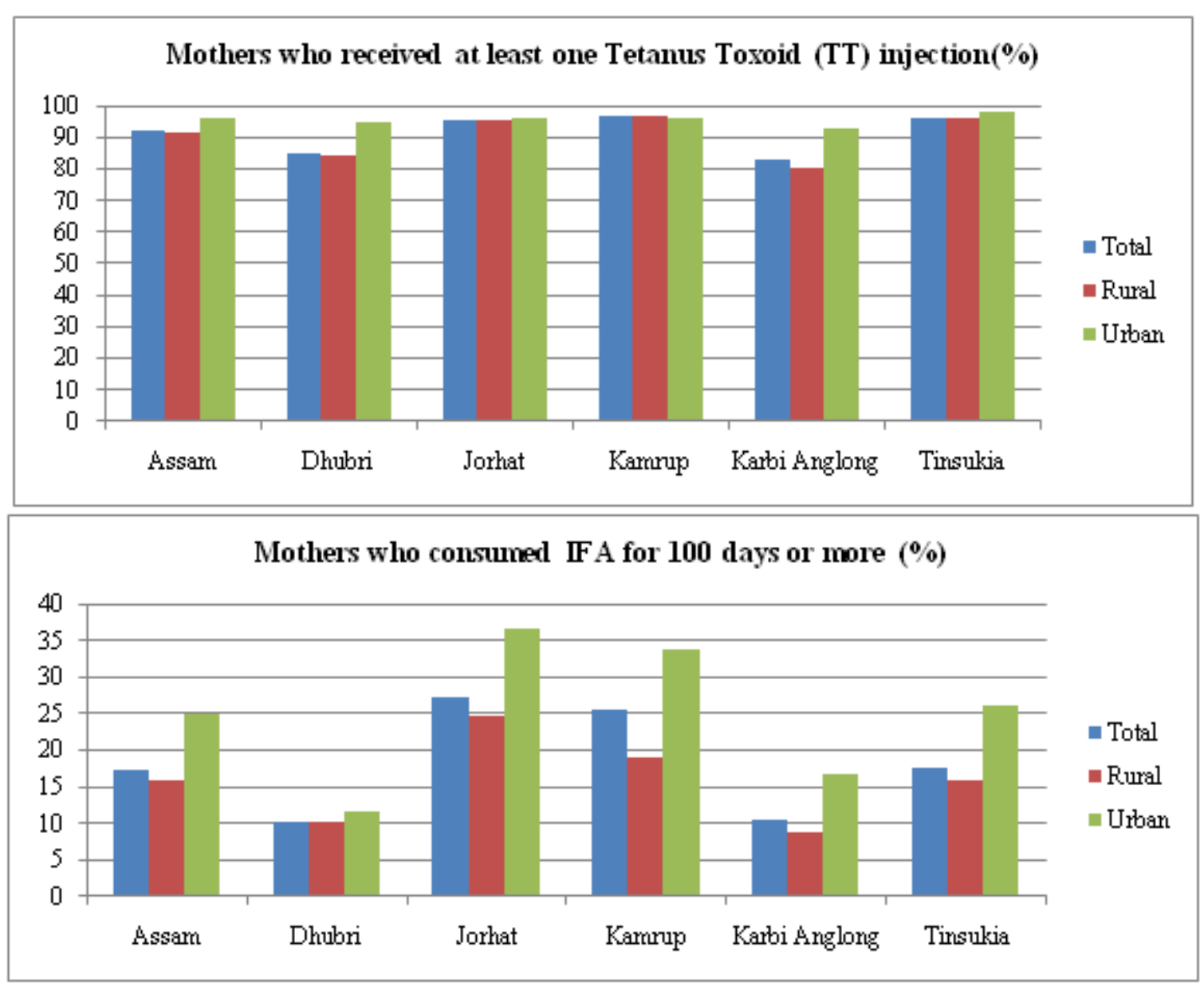

\section{Delivery Care}

Under Delivery care the details about place of delivery, type of delivery, source of transport provided/ availed for reaching in the delivery institution etc. are collected.

In Assam, the institutional deliveries have gone up. In 2006, there were only 66,000 institutional deliveries in Assam while 420,000 institutional deliveries have been recorded in the state $2010-2011$.

In 2005-2006, institutional deliveries in Assam increased by 39 percent compared to the year 2001-2002 and in 20112012., institutional deliveries increased by 212 percent compared to 2005-06 according to the NRHM report. The provision of delivery services in the government health institutions is one of the components of the Reproductive and Child Health Program ( $\mathrm{RCH})$.

In delivery care, for institutional delivery Kamrup has the highest number of cases where institutional delivery took place. Dhubri is highest where delivery at home took place and again Kamrup and Jorhat shows better performance in case of safe delivery .In rural region the districts that are performing well in institutional delivery, delivery at home and safe delivery are Kamrup, Dhubri and Jorhat. It can also be seen that urban regions of Dhubri and Karbi Anglong are performing better than the other selected districts in the indices of Delivery Care 


\section{International Journal of Science and Research (IJSR) \\ ISSN (Online): 2319-7064}

Index Copernicus Value (2013): 6.14 | Impact Factor (2014): 5.611

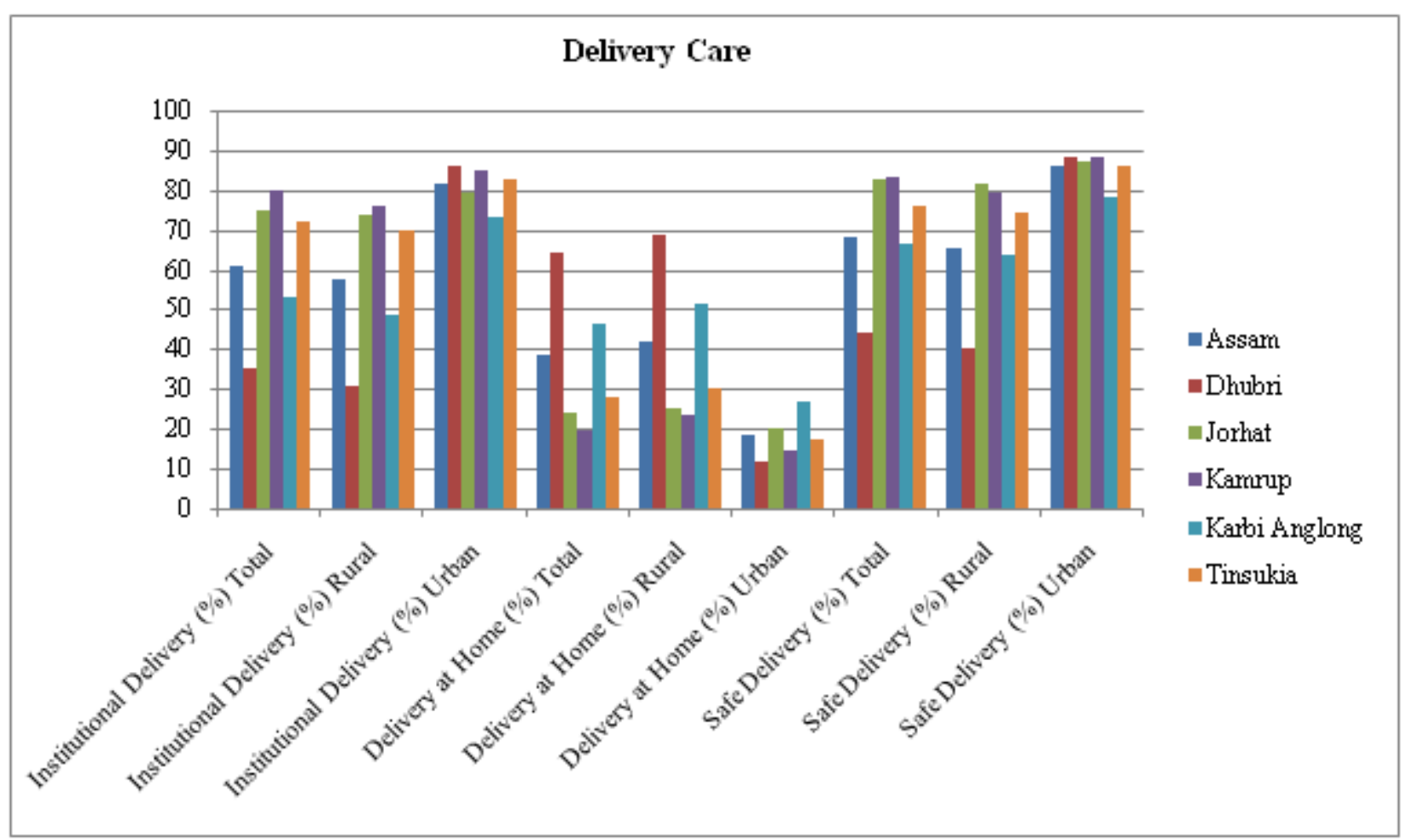

Postnatal Care: Postnatal care includes a minimum of two post partum home visits (first within 48 hours of delivery, second within seven to ten days) An initiation of early breast-feeding within half hour of birth. Counseling on diet and rest, hygiene, contraception, essential newborn care, infant and young child feeding. Information on like post natal checkup of mother, checkup of the new born etc. are collected from five districts and displayed in following figures.
Among the mothers in rural regions who receives post natal check up, Jorhat and Kamrup fare better than the rest, where as urban population of Dhubri is better than the other districts. In rural region amongst all the districts Dhubri is the one whose performance is low in receiving postnatal check up and in urban region Karbi Anglonges performance is poor than the other districts. In new born care Dhubries performance is better in urban region but poor in rural region. In rural Assam, Jorhat and Kamrup are performing better amongst others.

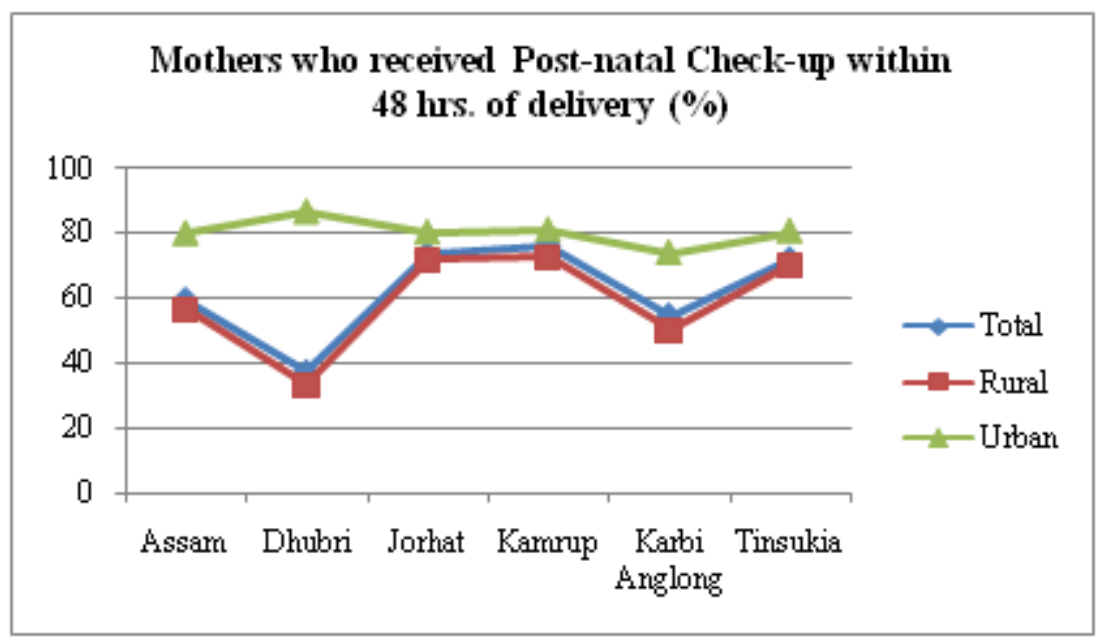


International Journal of Science and Research (IJSR)

ISSN (Online): 2319-7064

Index Copernicus Value (2013): 6.14 | Impact Factor (2014): 5.611

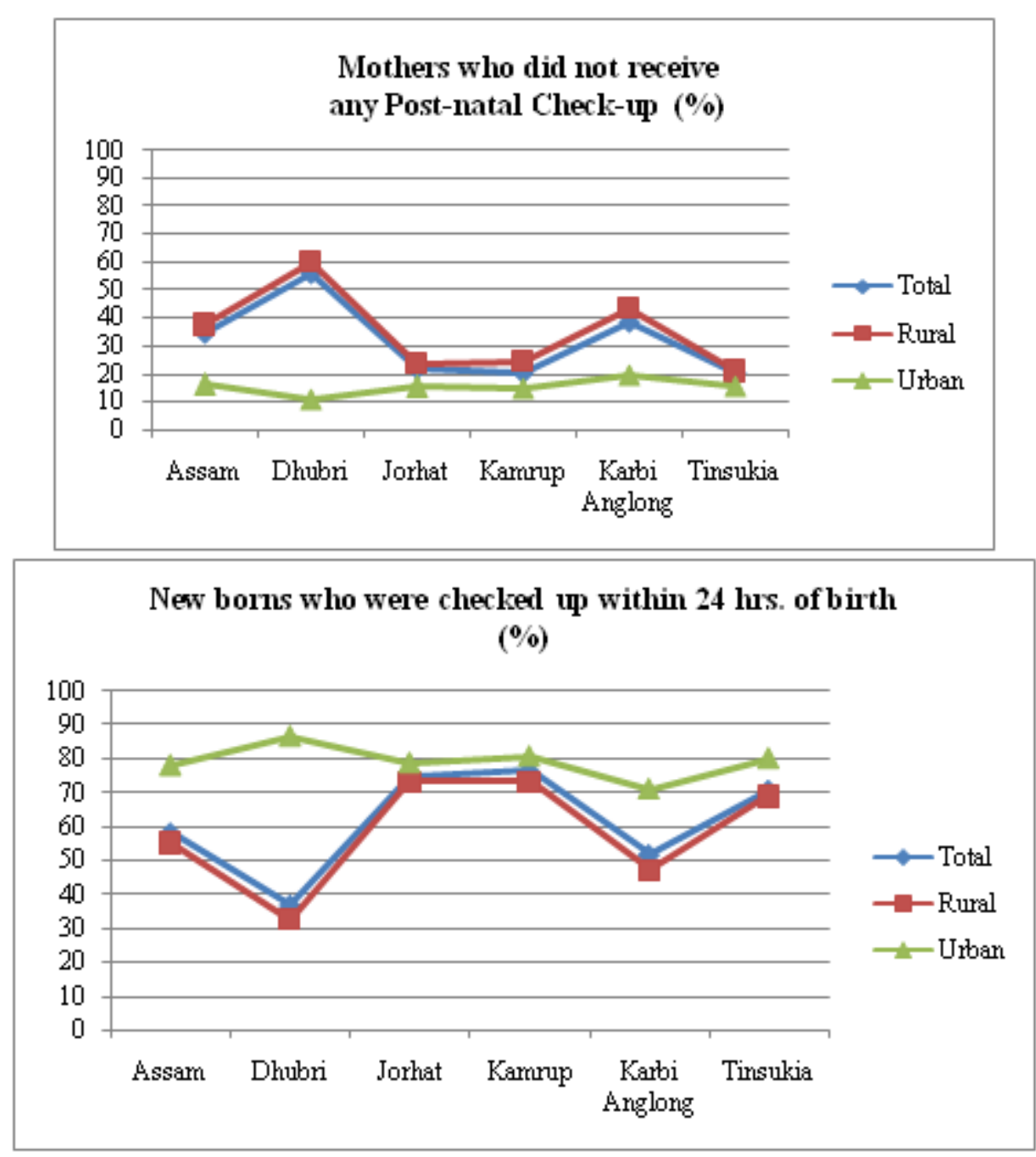

\section{Immunization}

The immunization of children against six serious but preventable diseases namely tuberculosis, diphtheria, pertusis, poliomyelitis and measles is the main component of the child survival program. As part of the national Health Policy, the National Immunization Program is being implemented on a priority basis. The Government of India initiated the Expanded program on Immunization (EPI) in 1978 with the objective of reducing morbidity, mortality and disabilities among children from six diseases. The information on childhood immunization i.e. vaccination coverage, has been collected on six vaccine preventable diseases viz. tuberculosis, diphtheria, whooping cough, tetanus, polio and measles for all living children. Vitamin A , Iron Folic supplement, birth weight, child feeding practices are some indicators associated with child health.

In this section the details of immunization has been shown in the graphs below along with birth weight and childhood diseases amongst the selected districts. Amongst the selected districts, Tinsukia fares the best regarding full immunization, immunization of polio, B.C.G performance etc. Amongst the selected districts though in urban region performance of Dhubri,,s urban region is better in terms of check up of new born, but fares worse in terms of the utilization of child health services like children who did not receive any vaccination, polio ,measles, BCG vaccination , and vitamin A supplementation.

\section{Breast Feeding}

Educating mothers on correct breastfeeding practices and child nutrition is one of the components of the $\mathrm{RCH}$ program. Infant feeding practices have significant effects on the health of both mother and children. Breastfeeding practices affect fertility and the length of birth intervals in general and postpartum fertility in particular. These effects vary according to the duration and intensity of breastfeeding. Proper infant feeding, starting from the time of birth, is important for the physical and mental development of the child. Breastfeeding improves the nutritional status of young children and reduces morbidity and mortality. Breast milk not only provides important nutrients, but also protects the child against infection. The timing and type of supplementary foods introduced in an infant"s diet have significant effects on the child"s nutritional status. 
IMMUNIZATION, VITAMIN A \& IRON SUPPLEMENT AND BIRTH WEIGHT 1
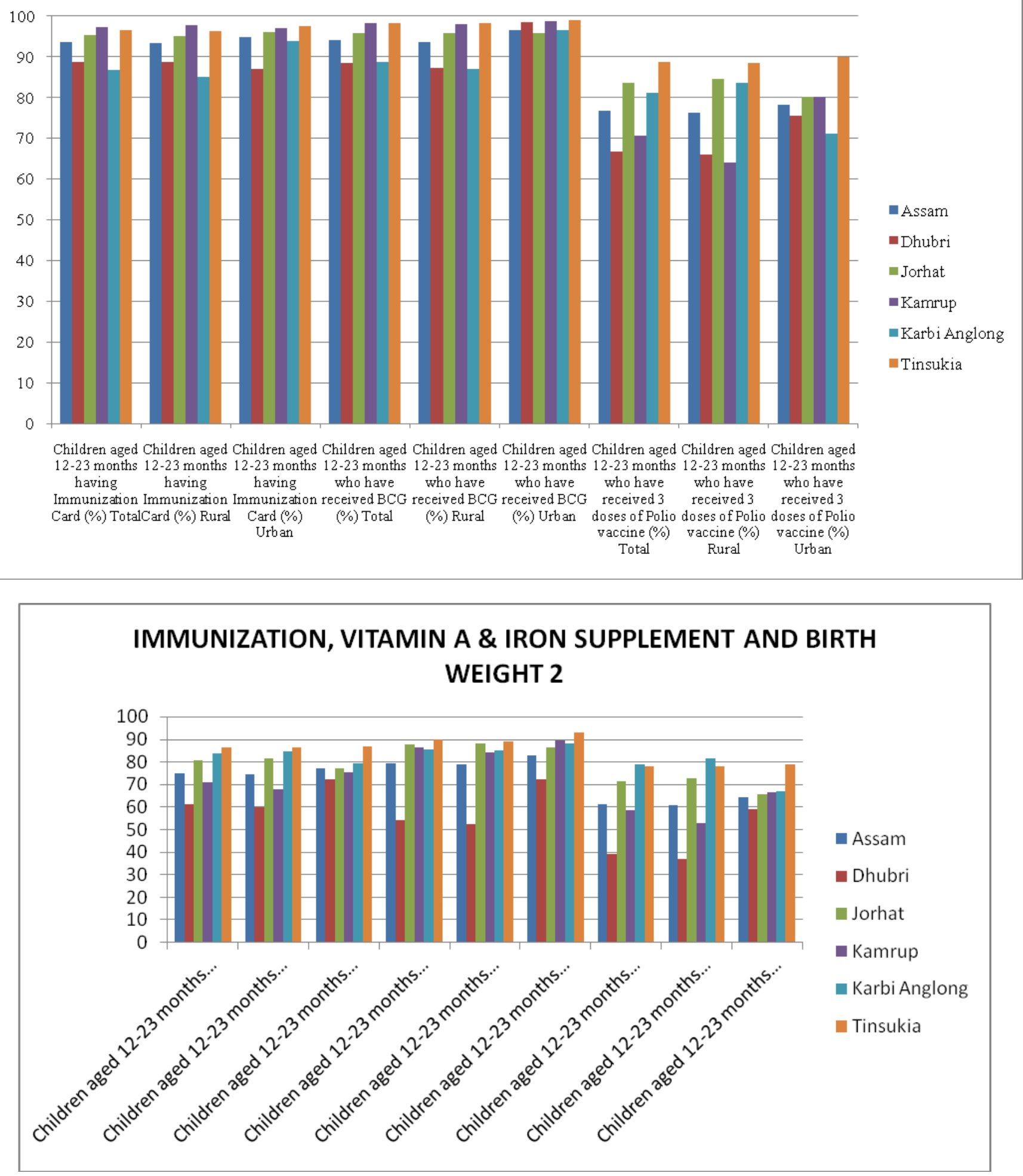

Volume 4 Issue 11, November 2015 


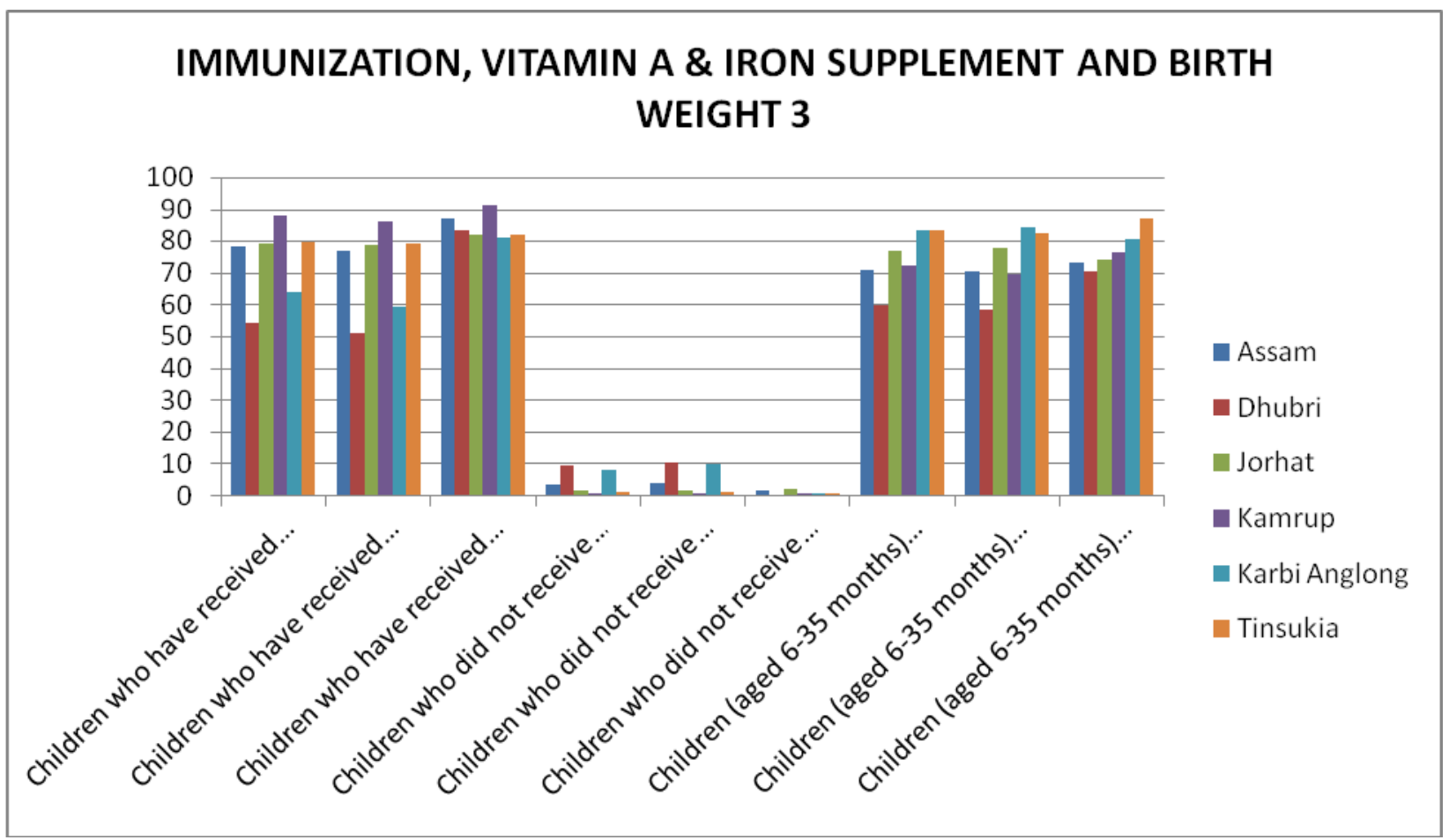

fig

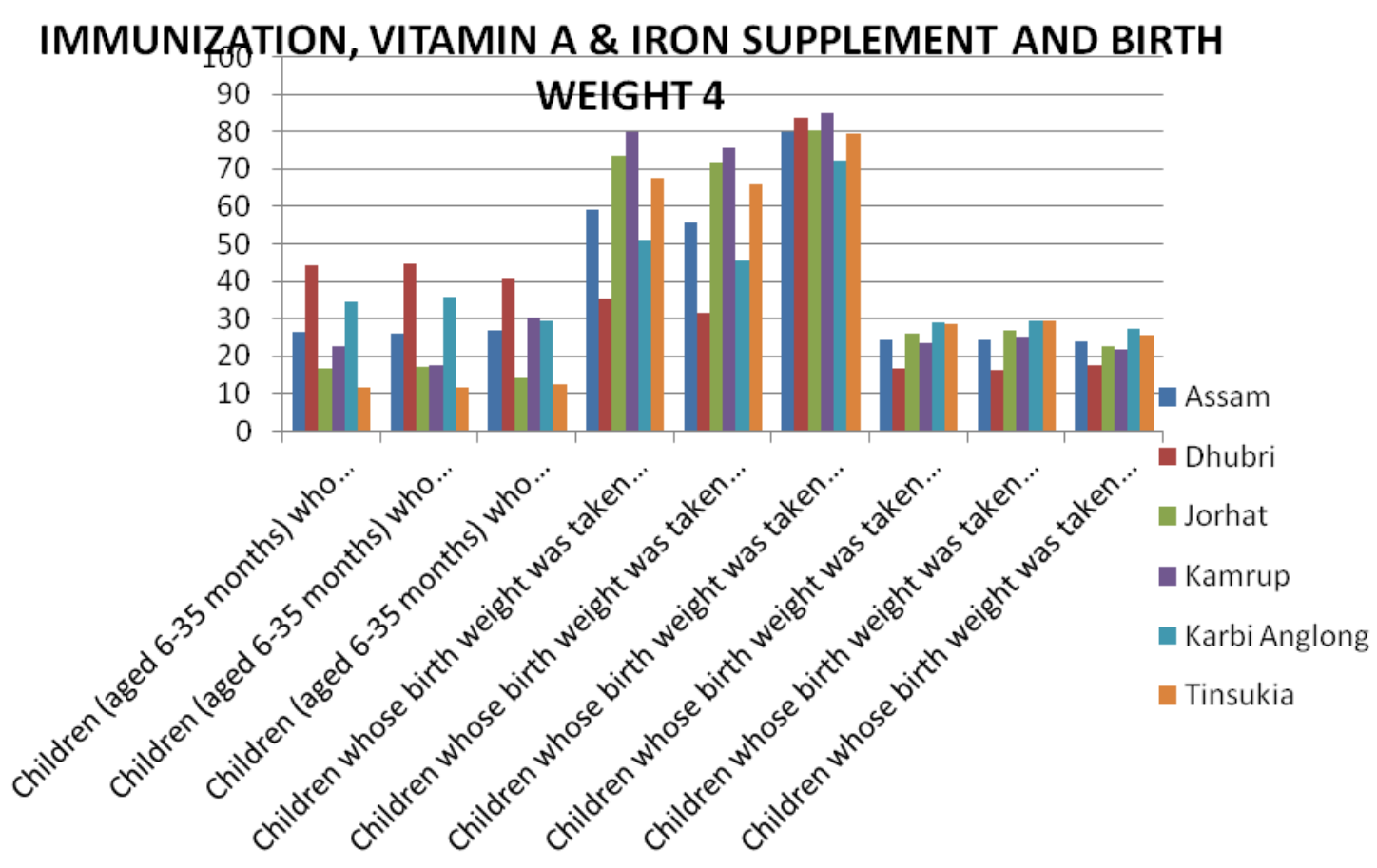

Volume 4 Issue 11, November 2015 

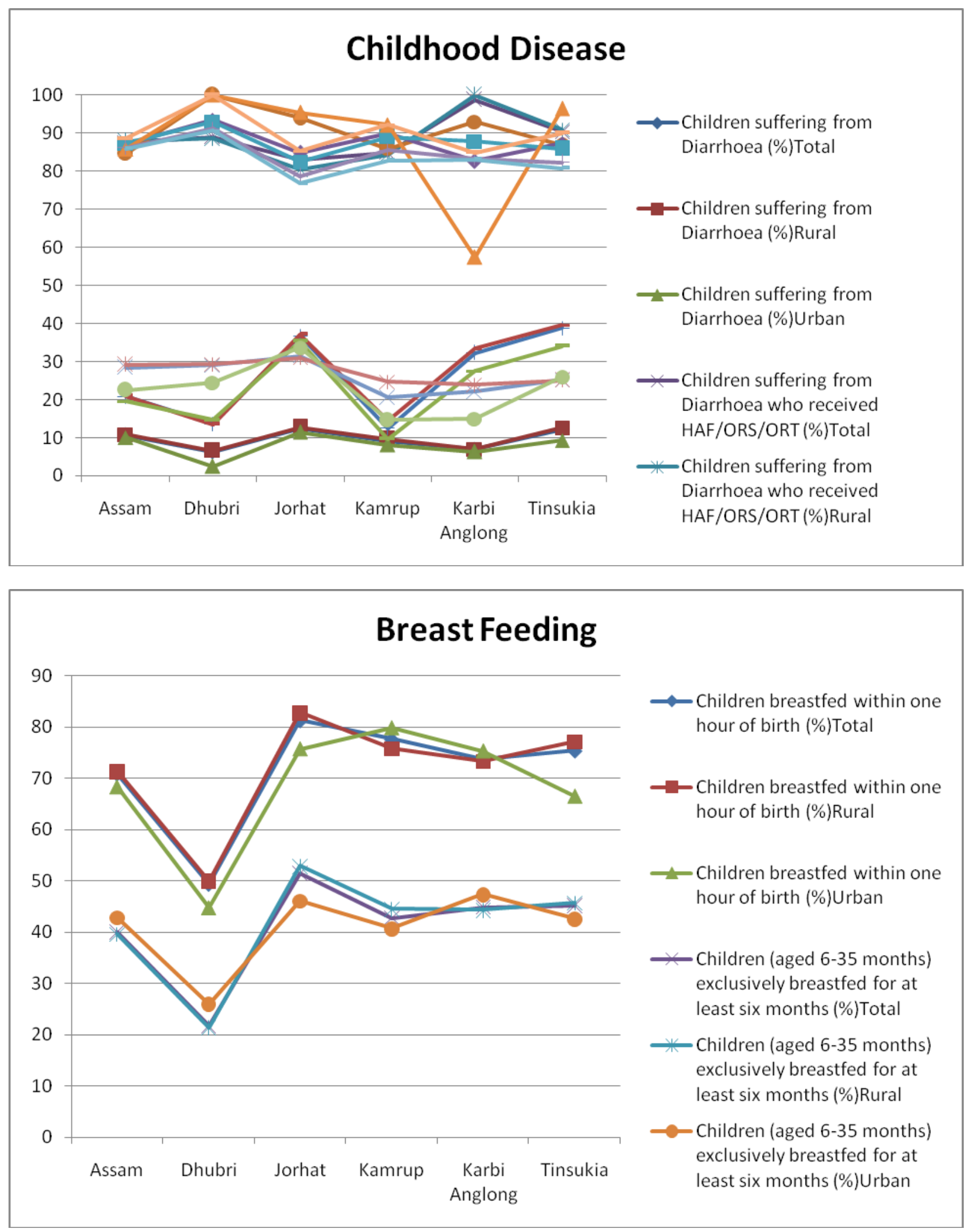

\section{Conclusion}

From the above study we have seen that Dhubri and Karbi Anglong are lagging behind in the socio economic indices like the literacy, sex ratio, work participation rate etc. These seem to have a direct implication on the mother and child health care, especially literacy rate. These two districts are lagging behind the rest in all the health care indices. Even between Karbi Anglong and Dhubri, Karbi Anglong is ahead of literacy rate in urban population, also in the health care indices. The only index in vital statistics Dhubri is ahead of the rest is Crude Birth Rate, which is highest among the Rural Population all districts.

When we look at the Antenatal care we see that Jorhat and Kamrup are well ahead of the rest of the districts, also there is hardly any difference between the indices of rural and urban population in these two districts. If we look at the other three districts, there is a stark difference in indices of 


\section{International Journal of Science and Research (IJSR) \\ ISSN (Online): 2319-7064}

Index Copernicus Value (2013): 6.14 | Impact Factor (2014): 5.611

rural and urban population. Among the all five districts under consideration, Dhubri lags the rest.

When we look at delivery care, the same story repeats. Dhubri lags all other districts in providing proper delivery care to the mothers. But here, urban population in Dhubri district seems to be better off. The same is true for the postnatal care. Here, Dhubries rural population lags by a significant amount, but the urban population either matches or ahead of the rest of the districts.

Coming to child health care, when we look at the immunization data of these districts, we can see that Tinsukia and Kamrup are ahead of the rest. Here, the urban population of each district is ahead of its rural counterparts. When we look at the graph use for showing children suffer from diseases, we see that Jorhat and Tinsukia are ahead of the rest. Here Dhubri seems to be doing well in both number of children suffering from either diarrhea or acute respiratory infection. Karbi Anglong along with Dhubri seems to provide better care for children, where as Jorhat and Tinsukia lags in these aspects. If we compare these results with the socio economic and demographic situations of these districts, we can see that districts with higher work population seem to lag in child care.

We can infer from these analysis is that there must be awareness among the illiterates mothers for antenatal and post natal care. Literacy helps in these cases, but for the illiterate people there must be schemes to attract them health care institutes. India's health and welfare ministry has come out with different schemes in this regard, but the message has not reached the illiterate people. Government working in collaboration with NGOs working in these areas must try to reach out these under privileged people for proper health care for the pregnant woman, new mothers and children.

The data seem to suggest that the working population neglect the child health care. Children healthcare is paramount and this message must go to the working parents.
This study has not taken into consideration the availability of proper health care facility in the rural areas. But if we see data for child healthcare seem to infer availability of some health care facility to the total population. What probably lacking is the proper awareness drive. Government initiatives must work towards building the awareness of healthcare among all the people. India ${ }^{e c}$ health care spending (as a percentage of GDP) is one of the lowest in the world. Same is the case with education. To build the future, Assam must take care that these two basic facilities reach its total population.

\section{References}

[1] Desai, Sonalde, WU, Lijuan and Josh,i B.L: Utilization of maternal health care services in India: Understanding the regional differences

[2] Factsheet of India: Maternal and child health in India and Norway India partnership initiative (NIPI)

[3] Annual health Survey( 2011-2012) Fact sheet Assam, vital statistics division, office of the registrar general and census commissioner, India, New Delhi, Website: www.censusindia.gov.in

[4] Census of India 2011: www.censusindia.gov.in

[5] Kharikar .P. Vijaya : Issues of maternal and child health care services among Muslims in selected cities India

[6] WHO (2006): Accomplishments, challenges and priorities . Project report on priorities in health 2006 , WHO

[7] Sharma ,Suresh (2007) : immunization coverage in India. working paper series no E/283/2007, Institute of economic growth New Delhi

[8] Eastern region report : Gender development indicators :District level analysis for the eastern region

[9] Dutta , Indrani and Bawari ,Shailly : Health and health care in Assam, A status report 
International Journal of Science and Research (IJSR)

ISSN (Online): 2319-7064

Index Copernicus Value (2013): 6.14 | Impact Factor (2014): 5.611

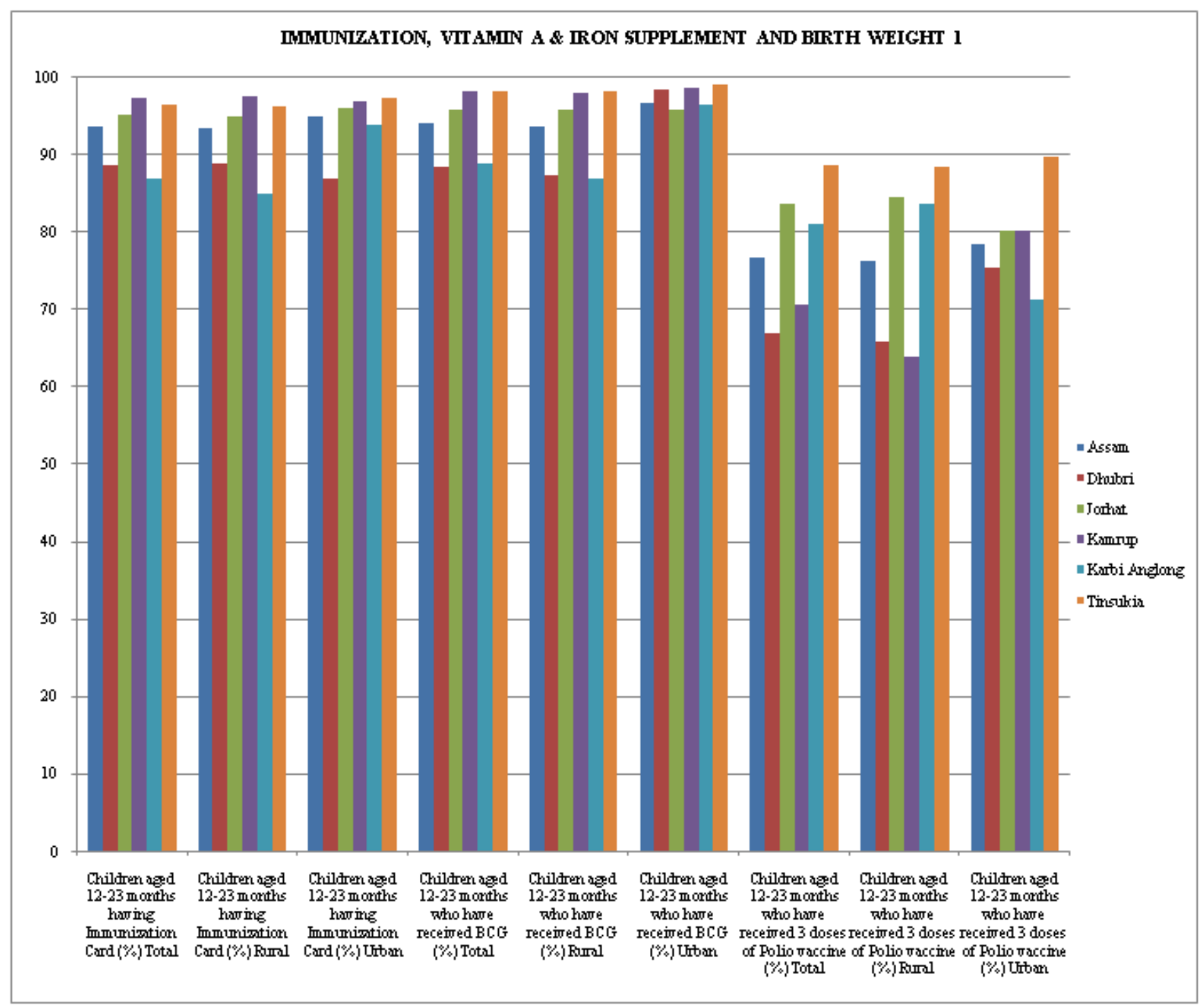

Volume 4 Issue 11, November 2015

www.ijsr.net 
International Journal of Science and Research (IJSR)

ISSN (Online): 2319-7064

Index Copernicus Value (2013): 6.14 | Impact Factor (2014): 5.611

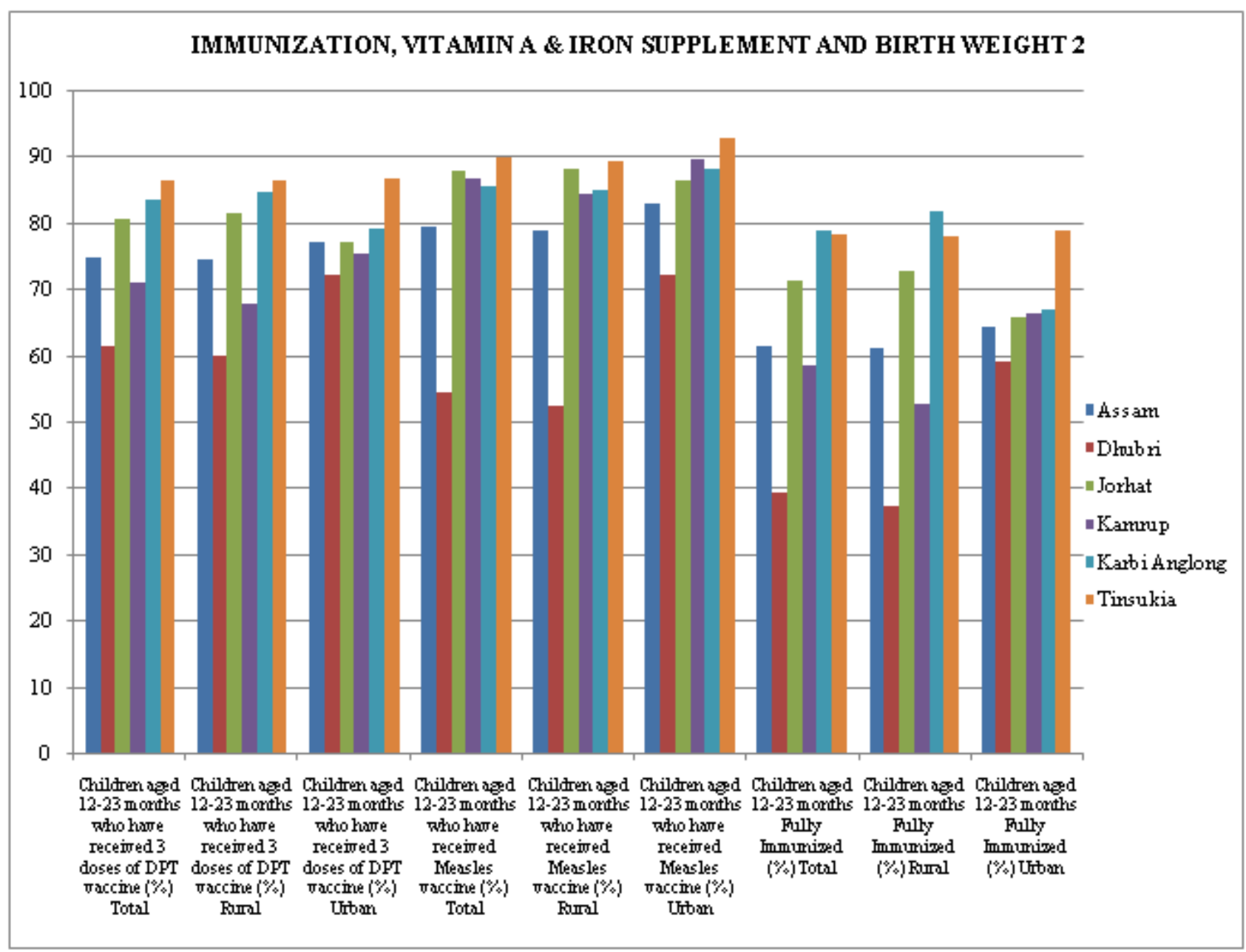

Volume 4 Issue 11, November 2015

www.ijsr.net 
International Journal of Science and Research (IJSR)

ISSN (Online): 2319-7064

Index Copernicus Value (2013): 6.14 | Impact Factor (2014): 5.611

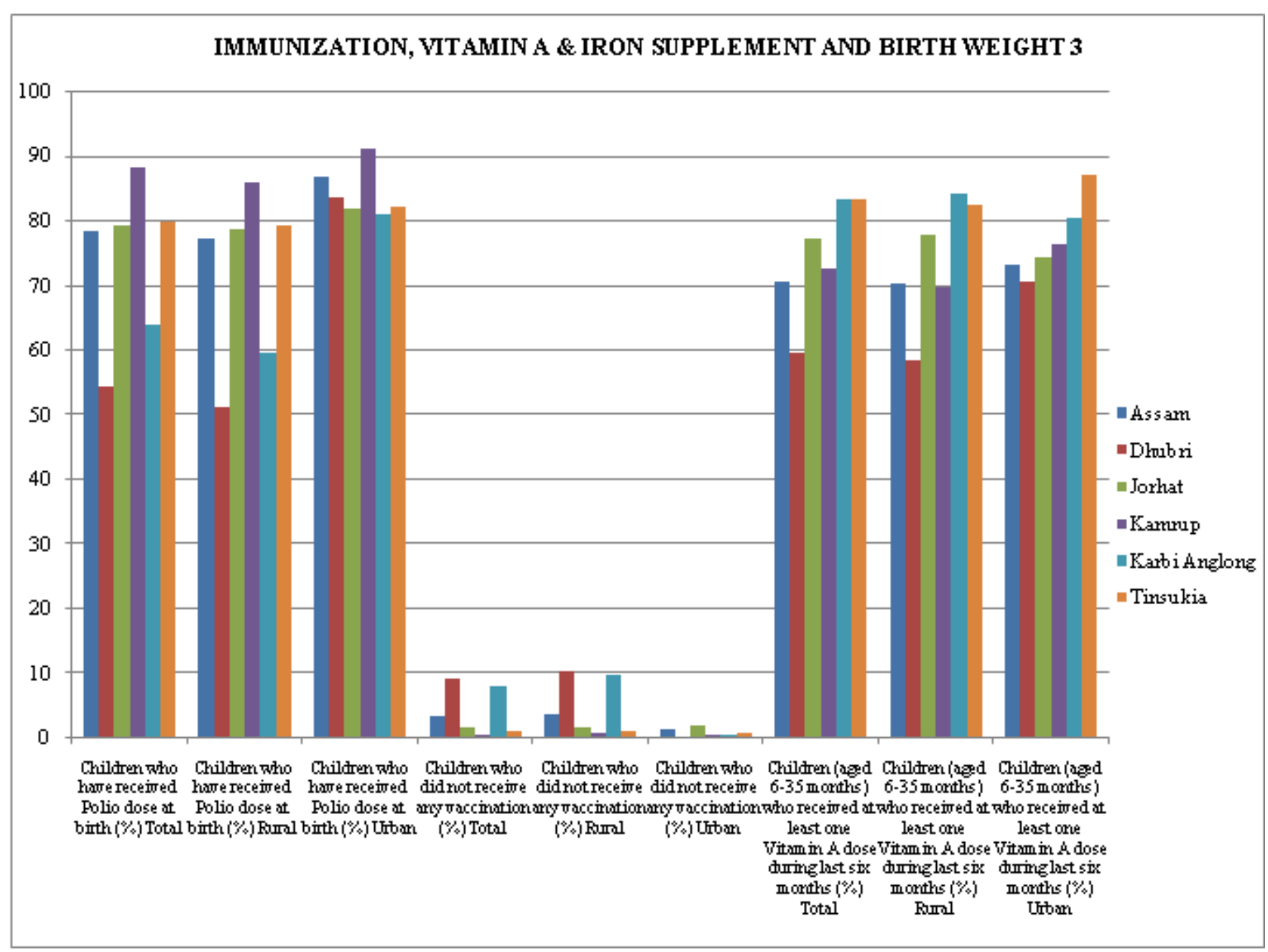

Volume 4 Issue 11, November 2015

www.ijsr.net 
International Journal of Science and Research (IJSR)

ISSN (Online): 2319-7064

Index Copernicus Value (2013): 6.14 | Impact Factor (2014): 5.611

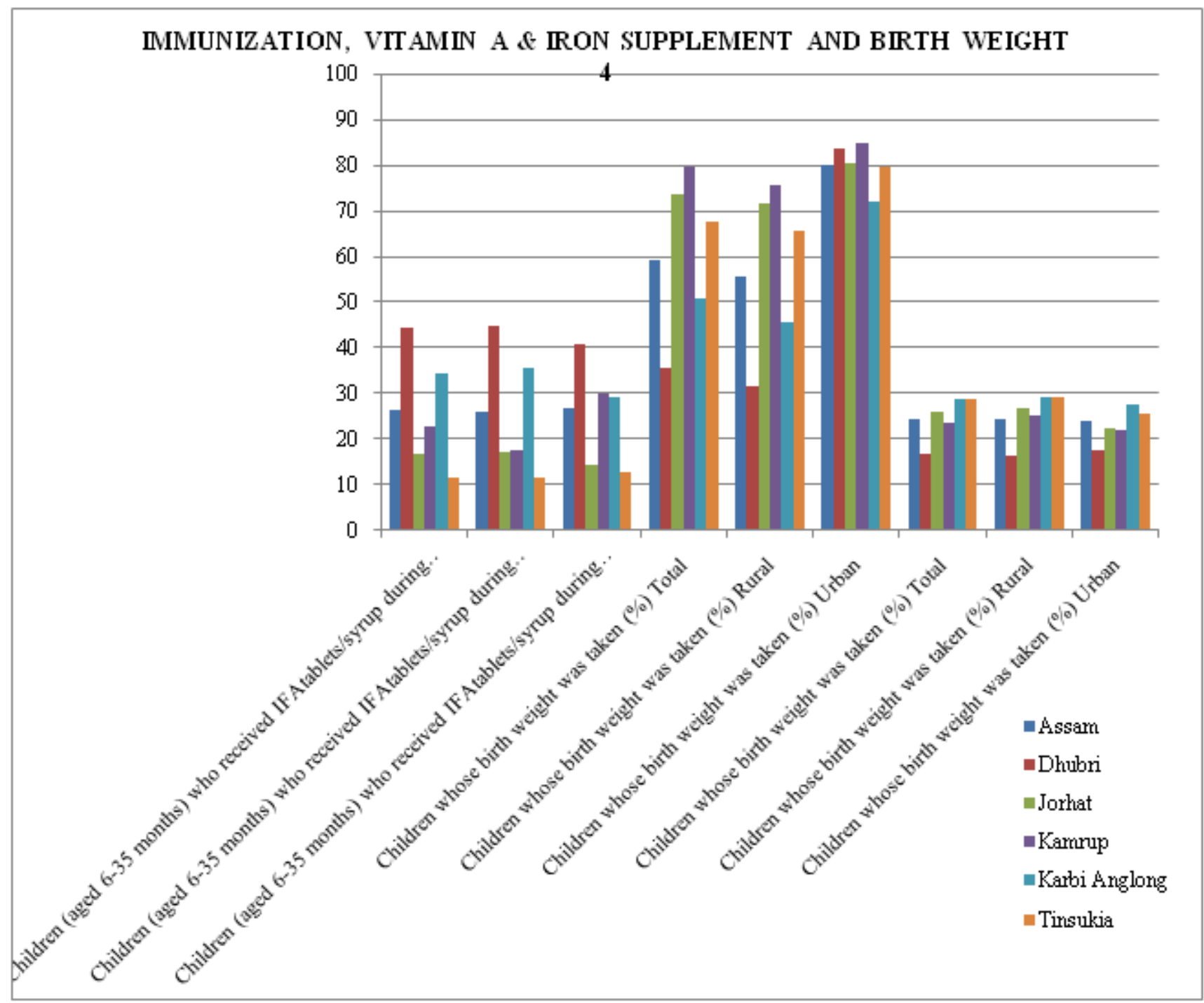

Volume 4 Issue 11, November 2015 


\section{International Journal of Science and Research (IJSR) \\ ISSN (Online): 2319-7064}

Index Copernicus Value (2013): 6.14 | Impact Factor (2014): 5.611
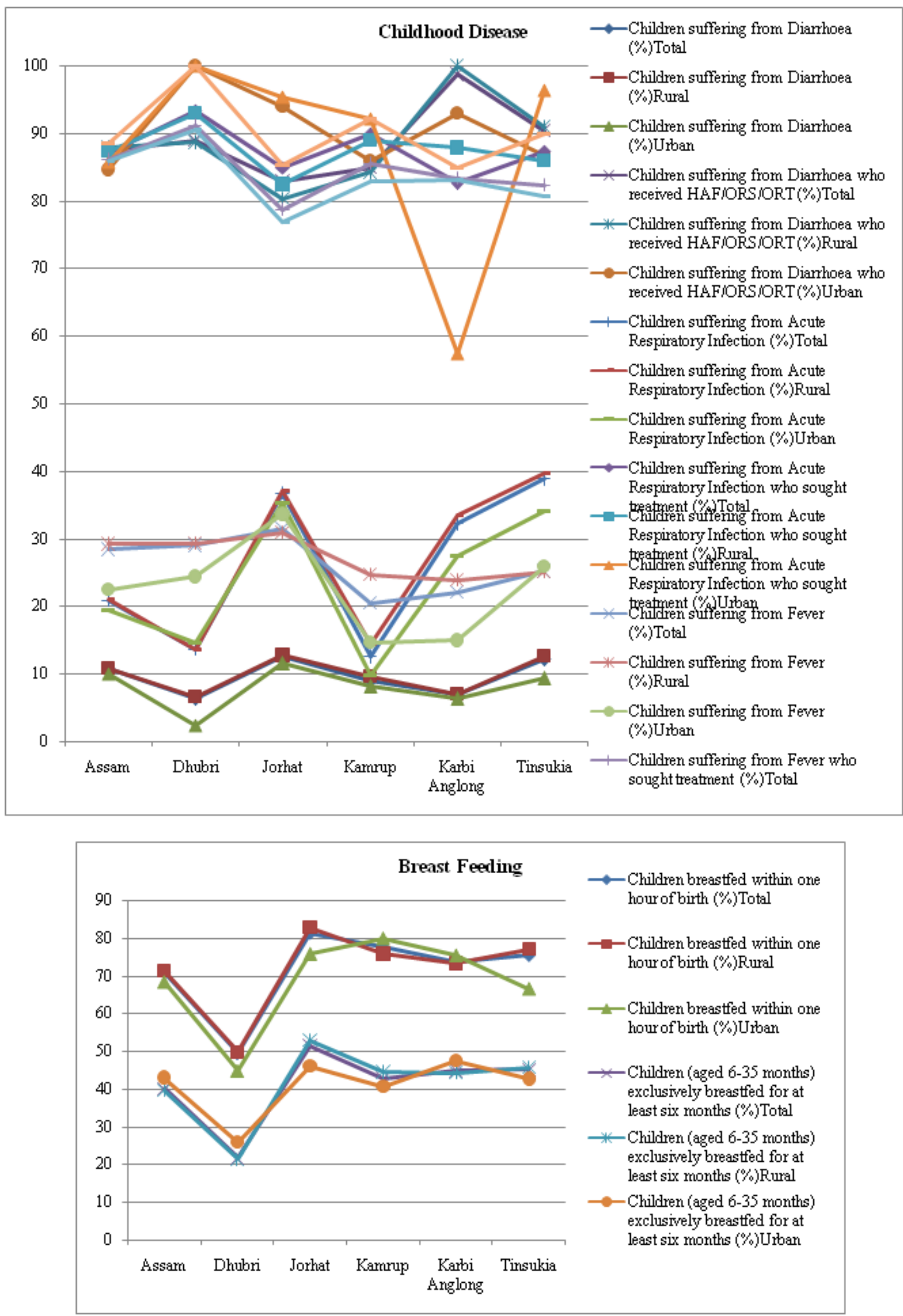

Volume 4 Issue 11, November 2015

www.ijsr.net 


\section{International Journal of Science and Research (IJSR) \\ ISSN (Online): 2319-7064}

Index Copernicus Value (2013): 6.14 | Impact Factor (2014): 5.611

\section{Conclusion}

From the above study we have seen that Dhubri and Karbi Anglong are lagging behind in the socio economic indices like the literacy, sex ratio, work participation rate etc. These seem to have a direct implication on the mother and child health care, especially literacy rate. These two districts are lagging behind the rest in all the health care indices. Even between Karbi Anglong and Dhubri, Karbi Anglong is ahead of literacy rate in urban population, also in the health care indices. The only index in vital statistics Dhubri is ahead of the rest is Crude Birth Rate, which is highest among the Rural Population all districts.

When we look at the Antenatal care we see that Jorhat and Kamrup are well ahead of the rest of the districts, also there is hardly any difference between the indices of rural and urban population in these two districts. If we look at the other three districts, there is a stark difference in indices of rural and urban population. Among the all five districts under consideration, Dhubri lags the rest.

When we look at delivery care, the same story repeats. Dhubri lags all other districts in providing proper delivery care to the mothers. But here, urban population in Dhubri district seems to be better off. The same is true for the postnatal care. Here, Dhubries rural population lags by a significant amount, but the urban population either matches or ahead of the rest of the districts.

Coming to child health care, when we look at the immunization data of these districts, we can see that Tinsukia and Kamrup are ahead of the rest. Here, the urban population of each district is ahead of its rural counterparts. When we look at the graph use for showing children suffer from diseases, we see that Jorhat and Tinsukia are ahead of the rest. Here Dhubri seems to be doing well in both number of children suffering from either diarrhea or acute respiratory infection. Karbi Anglong along with Dhubri seems to provide better care for children, where as Jorhat and Tinsukia lags in these aspects. If we compare these results with the socio economic and demographic situations of these districts, we can see that districts with higher work population seem to lag in child care.

We can infer from these analysis is that there must be awareness among the illiterates mothers for antenatal and post natal care. Literacy helps in these cases, but for the illiterate people there must be schemes to attract them health care institutes. India's health and welfare ministry has come out with different schemes in this regard, but the message has not reached the illiterate people. Government working in collaboration with NGOs working in these areas must try to reach out these under privileged people for proper health care for the pregnant woman, new mothers and children.

The data seem to suggest that the working population neglect the child health care. Children healthcare is paramount and this message must go to the working parents.

This study has not taken into consideration the availability of proper health care facility in the rural areas. But if we see data for child healthcare seem to infer availability of some health care facility to the total population. What probably lacking is the proper awareness drive. Government initiatives must work towards building the awareness of healthcare among all the people. Indiaes health care spending (as a percentage of GDP) is one of the lowest in the world. Same is the case with education. To build the future, Assam must take care that these two basic facilities reach its total population .

\section{References}

[1] Desai , Sonalde , WU, Lijuan and Josh,i B.L: Utilization of maternal health care services in India: Understanding the regional differences

[2] Factsheet of India: Maternal and child health in India and Norway India partnership initiative (NIPI)

[3] Annual health Survey( 2011-2012) Fact sheet Assam, vital statistics division, office of the registrar general and census commissioner, India, New Delhi, Website: www.censusindia.gov.in

[4] Census of India 2011 : www.censusindia.gov.in

[5] Kharikar .P. Vijaya : Issues of maternal and child health care services among Muslims in selected cities India

[6] WHO (2006): Accomplishments, challenges and priorities . Project report on priorities in health 2006 , WHO

[7] Sharma ,Suresh (2007) : immunization coverage in India. working paper series no E/283/2007, Institute of economic growth New Delhi

[8] Eastern region report : Gender development indicators :District level analysis for the eastern region

[9] Dutta , Indrani and Bawari, Shailly : Health and health care in Assam, A status report 
International Journal of Science and Research (IJSR)

ISSN (Online): 2319-7064

Index Copernicus Value (2013): 6.14 | Impact Factor (2014): 5.611

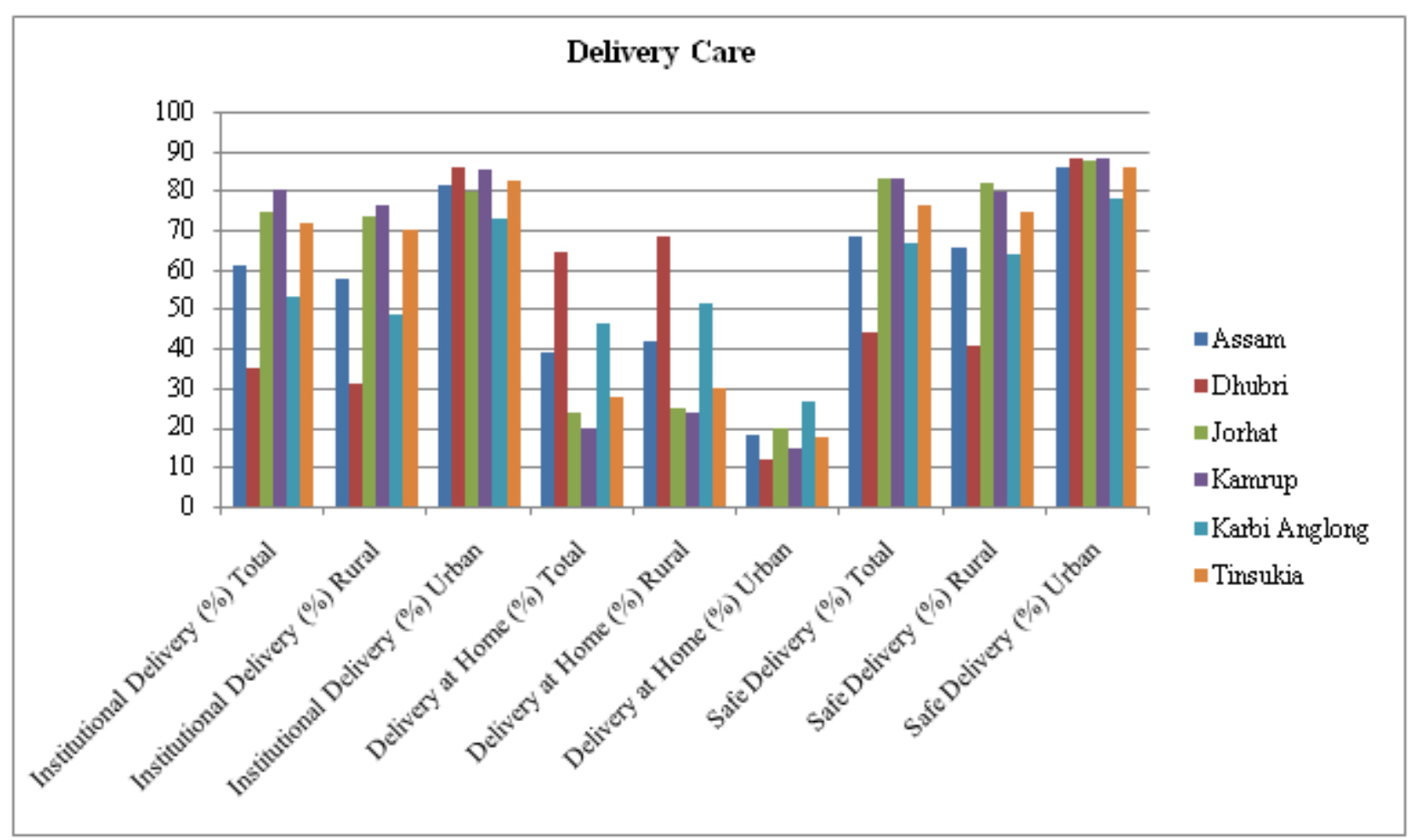

Volume 4 Issue 11, November 2015 